\title{
Revisiting the Churchyard
}

\author{
James Metcalf
}

King's College London

\section{ABSTRACT}

The churchyard has always been a site of pilgrimage. The remains of the dead, sanctified as holy relics, conferred a hallowed status on their location in the earth; this, in turn, became a destination for travellers. By the eighteenth century, 'pilgrims' consciously mapped their interest in literary remains onto these sacred spaces, drawing their pursuit of literary tourism into a long history of travel to the realms of the venerated dead. Using a series of photographs, I retrace my churchyard pilgrimages in London and Thomas Gray's Stoke Poges, reflecting on the context of thanatourism and thinking about the ways in which the places of the dead-chief among them the churchyard—still mean today.

Keywords: Thomas Gray, churchyard, pilgrimage, thanatourism

\section{ST. DUNSTAN-IN-THE-EAST, 23 SEPTEMBER 2016}

The first time I saw the ruined church of St. Dunstan-in-the-East (between London Bridge and the Tower of London) I was riding down Cycle Superhighway no. 3 on an old bike with a buckled rear wheel. I had arrived in London a month earlier and had become familiar with my route from the east into the centre. As it weaves from Whitechapel through the City of London and onto Victoria Embankment, the CS3 passes many churches. When I had time I would trail off the cycle-path and wander around the buildings and their grounds; I had already taken pictures and made notes in All Hallows by the Tower, St. Olave's on Hart Lane (where Samuel Pepys 
is buried), and St. Michael Paternoster Royal on College Street. These sites contain churchyards repurposed as green spaces, with benches on which businessmen sit to lunch; on the City Gardens Map they are identified with a cross and a patch of grass-green ink. As places for pause, these churchyards are on-the-way-emerging from the roadside as stopping places, they transfigure the commute into something like a pilgrimage with staggered way stations. ${ }^{1}$

St. Dunstan-in-the-East is almost hidden from the road-it requires peering round a corner, which is difficult on the steep hill. There are times of the day when a crush of other cyclists makes peripheral vision a strategic necessity rather than a sightseeing luxury. I first saw it travelling the other way-coming home at night when up-hill-going was slower, and it was late, and I had time to wonder what might be round a bend or down an alley. The tower points gracefully, hides decorously, lucent white against enclosing grey. At night it is lit from below, spectral and stark. Gothic tracery is covered in ivy-empty arches re-filled with a fine filigree of coiling tendrils. There is no roof and treetops are visible from what ought to be the nave, but the walls are strong.

The next day I set off early; chaining my bike to the railings, I am armed with a phone for taking photographs and a thick black notebook for jotting down available information. I re-inscribe a plaque in paraphrase: ancient Saxon site, restored by St. Dunstan 950AD; church originally built c.1100, damaged during the Great Fire; tower and steeple added by Wren 1695-1701, the rest rebuilt in 1817; partially destroyed by WWII bombing 1941 (tower \& steeple survived); garden created by the Corporation of London and opened 1970-won prizes as public garden

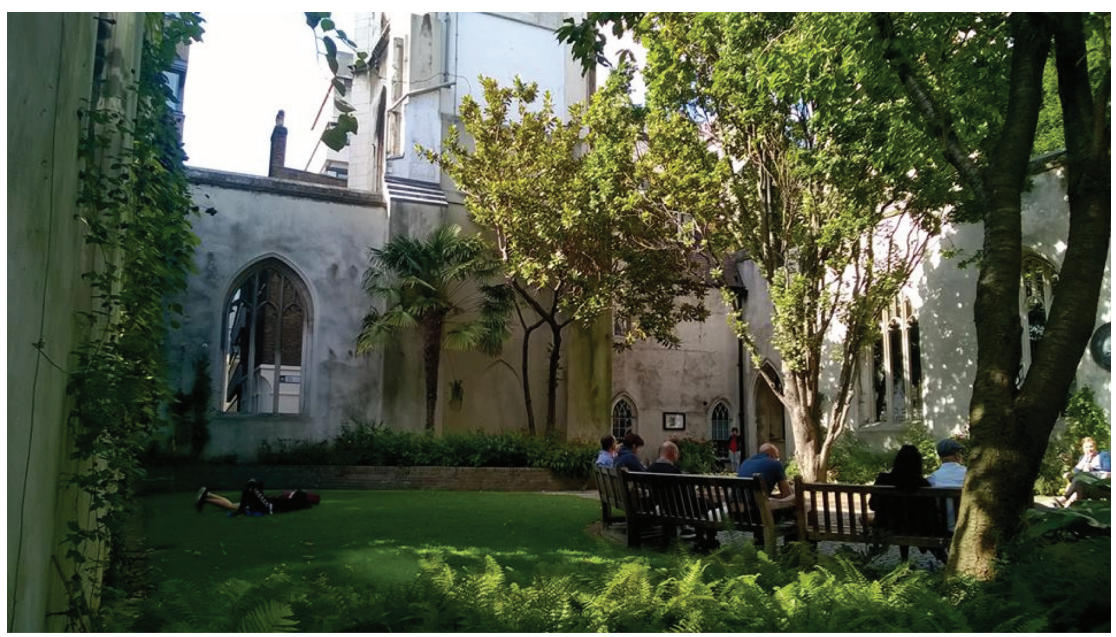




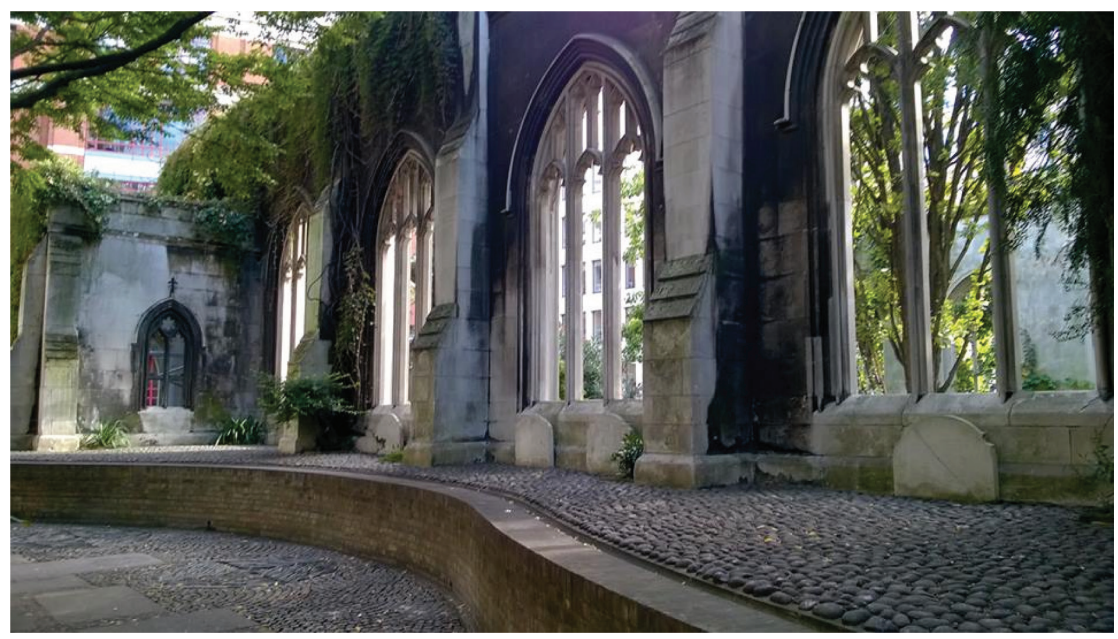

square. This is supplemented by a hasty sentence of praise and more concentrated observation: Astonishing ruin, tenanted by worn headstones artistically arranged (only four visible), close to indecipherable-one for Thomas Sanders (unknown date); others indistinct.

In the centre of the shell there is a circle of benches, surrounded by trees and raised beds, where people perch with their morning coffee, books and newspapers. The soil is crowded with ferns. Around the outside, where the walls are stained to charcoal, there are terraced walkways in cobbles and flagstones. Cinquefoil arches incongruously frame the Shard's rectilinearity-London's habit of juxtaposition, still startling.

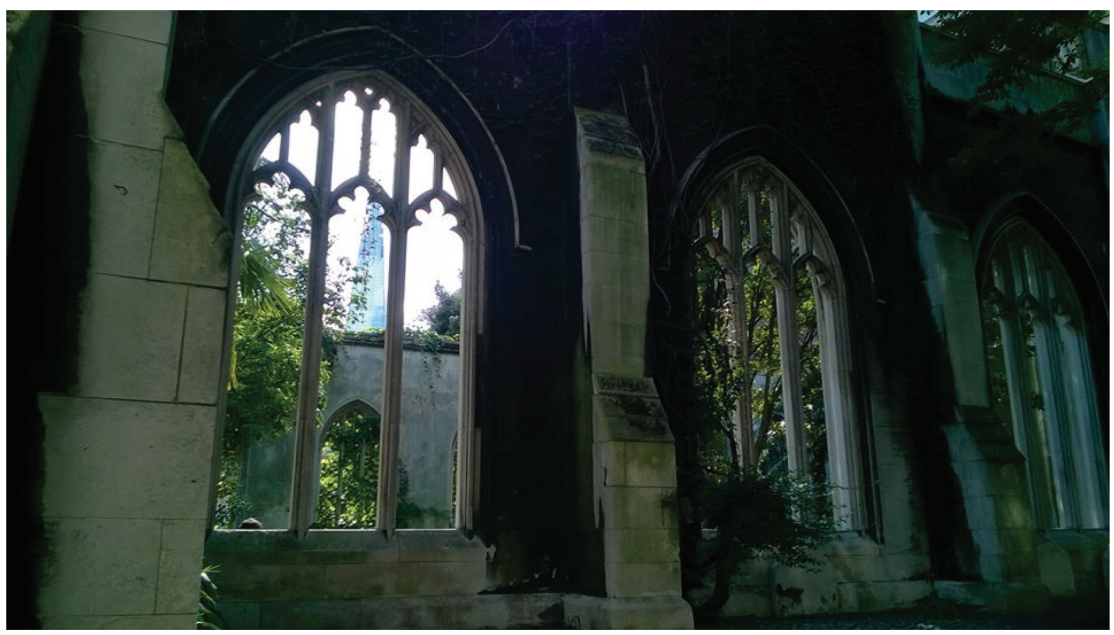


Leaving the university later that afternoon, I go back to the ruin with a new book of poetry. I read:

In sad and ashy weeds

I sigh, I pine, I grieve, I mourn;

My oats and yellow reeds

I now to jet and ebon turn.

My urgèd eyes,

Like winter skies,

My furrowed cheeks o'erflow.

All heaven knows why

Men mourn as I,

And who can blame my woe? ${ }^{2}$

I call home, trying to describe what I have discovered, the poem and the place, their interlacing. I am reminded of a picture: four years old, I peer down from the crumbling window of a Welsh castle. Here, now, I watch wedding photos being taken by the tower, white gown and veil flashing white against white stone.

I have always been interested in the pull of place-particularly the ways in which ancient places still mean. ${ }^{3}$ One of the ways in which churchyards still mean is evident in their reclamation and re-use over time. As burial has increasingly taken place elsewhere (graveyards, cemeteries, crematoria, natural spaces) they have become sanctuaries for wildlife: rabbits, moles, and rodents that crop, disturb, and peer through the grasses and wildflowers clustered around the grave, or the birds that

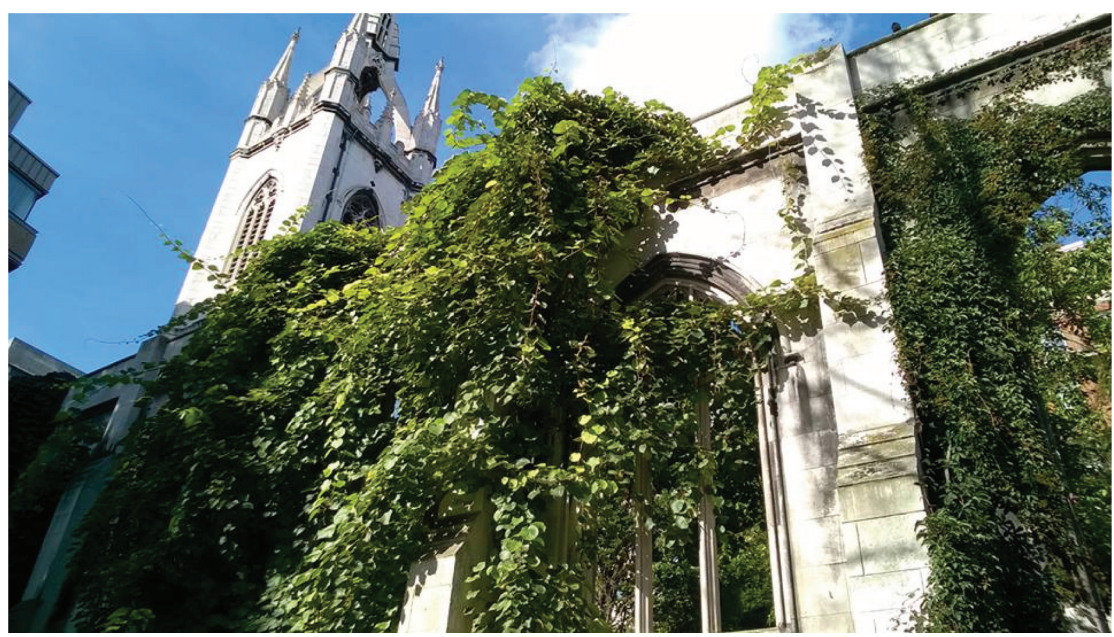


perch on a headstone made of local material on which rare mosses proliferate; native trees like yew and rowan that have a mythography deeply rooted in the churchyard earth. ${ }^{4}$ Another stage in their continued use is deeply human: interview data suggest that churchyards remain what they have always been-embedded in the lives of local communities. Respondents refer to them as sites of contemplation and melancholy-affects that charge the landscape with internal meaning and, perhaps, draw on centuries of poetic preoccupation with this particular place-but also as places for recreation, from jogging and walking the dog to drinking and (euphemistically) 'enjoying romantic pursuits': 'churchyards are replete with life as well as death.'

Eighteenth months later, in May 2018, I'm speaking at a conference. During the lunch break I play a photo-reel of modern churchyardsa collection of a co-organiser's rural discoveries with my own London churchyards, including St. Dunstan-in-the-East. The spire, the ivy, the empty arches flash across the screen and are gone, echoes of a vanishing. I forget to loop the reel; someone touches my arm, mid-conversation, compelling silent attention: 'Could you please play those photographs again? They are beautiful.'

\section{STOKE POGES, 3 NOVEMBER 2018}

The PowerPoint images drive me to a place I have always intended to visit. Walking from the train station at Slough to St. Giles' Church in Buckinghamshire, I pass the topographical indexes of the area's most famous posthumous resident: I walk along Gray's Road and Gray's Place, before reaching Gray's Field. This patch of land-presented to the National Trust by two local residents who purchased it in 1921-is marked by a sign inviting visitors to 'make the most of Thomas Gray Landscape', encompassing the field, the church, a museum, and (anachronistically) a memorial garden created in the 1930s. This eponymous 'Landscape' was 'immortalised' in Gray's Elegy Written in a Country Churchyard (1751) (a stanza of which the billboard quotes), and St. Giles' churchyard is maintained as "the setting of Gray's famous "Elegy" and also where you can find Gray's tombstone and those of his beloved family members'.

In 'Gray's Field' there is a five-metre high monumental pedestal of brick faced with Portland stone and topped with a sarcophagus designed by James Watt and commissioned by John Penn of neighbouring Stoke Manor in 1799 (28 years after Gray's death in 1771). The memorial is mounted with three tablets containing stanzas from the Elegy and the Ode on a Distant Prospect of Eton College (1747). These lines in this place have the effect of site-specific loco-description, directing the visitor to the 
surrounding scene and identifying Gray with the personae of his poems; writer and poetic narrator seem to share a history and a grave in Stoke Poges. The monument stands for place-and for this particular place's interaction with and expression in poetry - as much as for a long-dead writer.

Churchyards still mean today-as they did in the eighteenth centurythrough the writing they inhabit and inspire. Stoke Poges-where Gray's mother and aunt lived, and where Gray paid many visits throughout his life-is saturated with the memory and maintained presence of the poet. He is buried in a chest tomb next to both the church and the tomb of his mother (for which he composed an epitaph), but his status as the genius loci of Stoke Poges is conferred by something extra-bodily. 'As Shakespeare is the tutelary genius of Stratford-on-Avon, so Stoke Poges is inseparably connected with the memory of Gray', the guide available in the church remarks. ${ }^{6}$ A guide to 'Thomas Gray, Poet' by the same parish vicar quotes a letter dated 24 December 1798, written by Jacob Bryant who claimed to know Gray. During the poet's visits to Stoke Poges, Bryant relates, he

was obliged to pass by the church-yard which was almost close to the house and he would sometimes deviate into it and there spend a melancholy moment. The stillness and solemnity of the season after sunset, and the numerous dead deposited before his eyes afforded room to a person of his turn for much contemplation. His own pensive mood and the gloomy yet pleasing ideas which then arose are described by him in the poem which was styled 'Elegy written

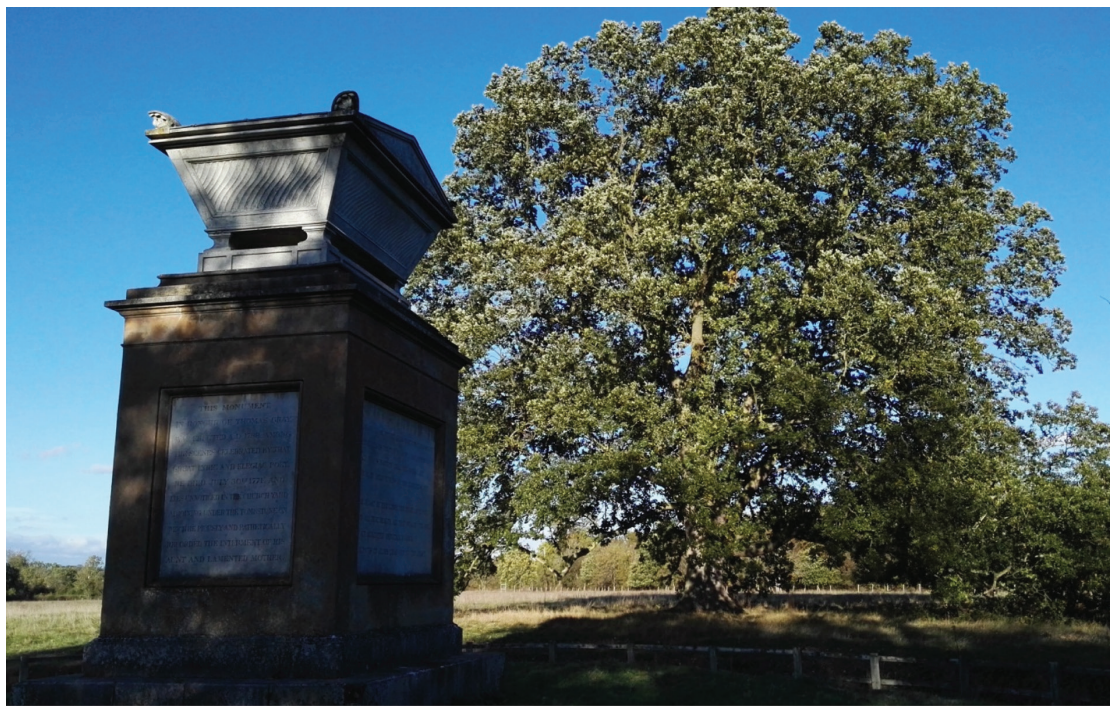


in a Churchyard'. It was certainly conceived and many of the stanzas probably there composed when the awful scene was before his eyes[.] ${ }^{7}$

The combined presence of Gray's body and his most famous poem in Stoke Poges Churchyard is powerfully reflected in a still-elegiac landscape: 'The material reality of Gray's grave was progressively redesigned to correspond with "the grave of the author of the Elegy"', 'a place where readers could confidently come to find an English poet at one with the English soil'. Gray's work is 'progressively and differentially locked to place', and his Elegy appears to script the literary and thanatourism that followed. ${ }^{8}$ There have been countless visitors to Stoke Poges since Gray's death-pilgrims who briefly and spectrally inhabit the role of the 'kindred Spirit' who enquires the narrator's fate at the end of the poem. ${ }^{9}$ Many have written poems and travelogues about the pull of Gray's churchyard. In 1853, Harriet Beecher Stowe stopped to recite the Elegy in a churchyard she later discovered to be the wrong one, consoling herself with the fact that 'the emotion was admirable, and wanted only the right place to make it the most appropriate in the world'. ${ }^{10}$ The alignment of emotion and place is expressed in Robert Montgomery's 'The Tomb of Gray' (1836), for

'Twas here he mused; here Poetry and Thought,

And Silence, their enamour'd Sister, came;

And Taste and Truth their kindred magic blent[.] ${ }^{11}$

To stand in Stoke Poges Churchyard is to stand beside its resident poet, 'Form'd into life by Fancy's moulding spell' (1. 39).

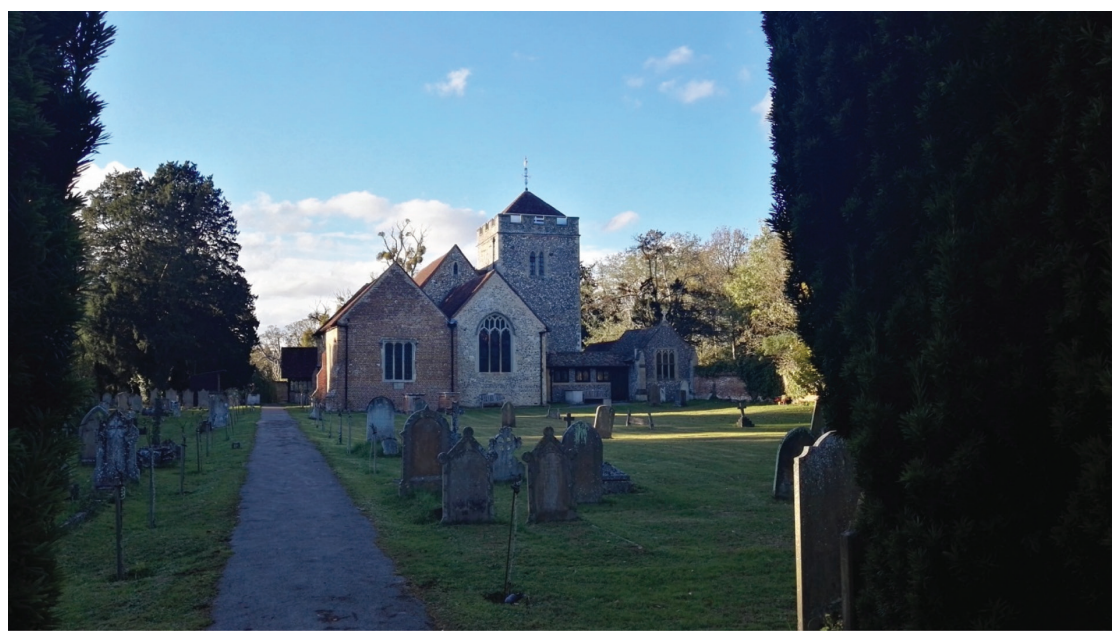


Other visitors have made other art of the churchyard, including stillvisible graffiti epitaphically etched into the poet's tomb. In 1850, S. C. Hall remarked that the "churchyard was full, very full [...] and a wonderful quantity of persons visited it and read the epitaphs, and even scratched their names on the church walls, though it was forbidden, and took away bits of the yew and wild flowers.' ${ }^{12}$ Still others (I imagine) have sat and reflected.

The tombs of Gray and his mother, and beyond them the larger crowd of the churchyard dead, are fleetingly dappled by fading sunlight and the shades of encroaching dusk. On a bench against the church wall, looking out across this mortal community, I read:

Beneath those rugged elms, that yew-tree's shade,

Where heaves the turf in many a mouldering heap,

Each in his narrow cell for ever laid,

The rude forefathers of the hamlet sleep.

$[\ldots]$

Perhaps in this neglected spot is laid

Some heart once pregnant with celestial fire;

Hands that the rod of empire might have swayed,

Or waked to ecstasy the living lyre.

[...]

On some fond breast the parting soul relies,

Some pious drops the closing eye requires;

Ev'n from the tomb the voice of nature cries,

Ev'n in our ashes live their wonted fires. (1l. 13-16, 45-48, 89-92)

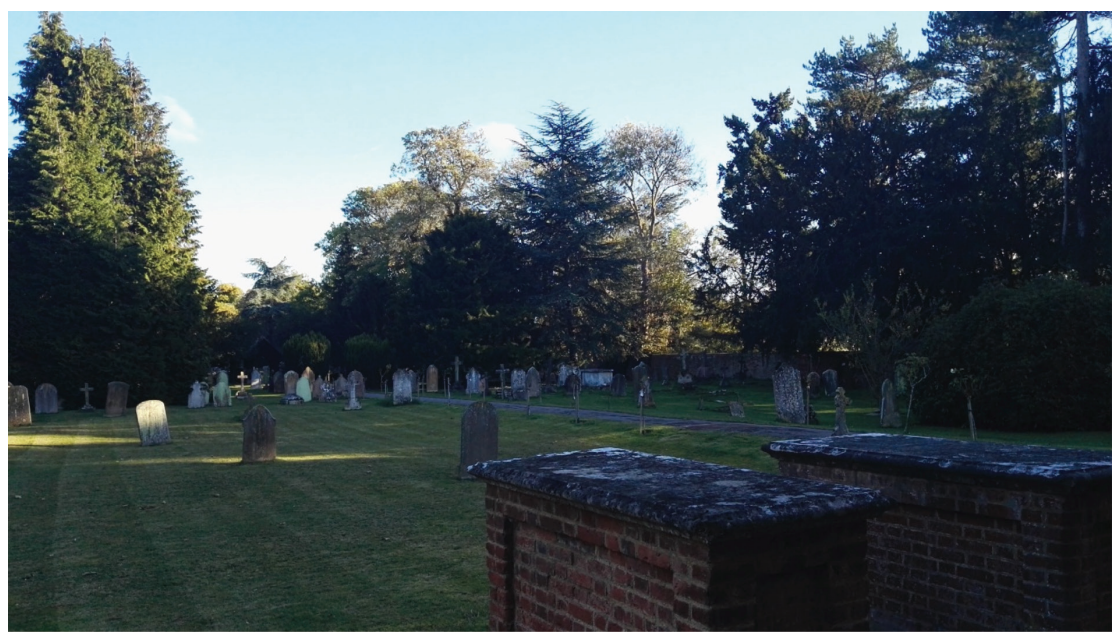




\section{WORKS CITED}

Ariès, Philippe. The Hour of Our Death (1977). Trans. Helen Weaver. Oxford: Oxford University Press, 1991.

Buczacki, Stefan. Earth to Earth: A Natural History of Churchyards. London: Unicorn Publishing Groups, 2018.

Dee, Tim (ed.). Ground Work: Writings on Places and People. London: Vintage, 2018.

Deering, Bel. 'From Anti-Social Behaviour to X-Rated: Exploring Social Diversity and Conflict in the Cemetery.' In: Avril Maddrell and James D. Sidaway (eds.), Deathscapes: Spaces for Death, Dying, Mourning and Remembrance. Farnham: Ashgate Publishing Ltd., 2010, 75-95.

Foster, Shirley. 'Americans and Anti-Tourism.' In: Nicola J. Watson (ed.), Literary Tourism and Nineteenth-Century Culture. Basingstoke: Palgrave Macmillan, 2009, 175-183.

Gray, Thomas. 'Elegy Written in a Country Churchyard' (1751). In: Roger Lonsdale (ed.), The Poems of Thomas Gray, William Collins, Oliver Goldsmith. London: Longmans, 1969, 103-142.

Hall, S. C. Pilgrimages to English Shrines. London: Arthur Hall, Virtue, \& Co., 1850.

Harris, Reverend C. E. A Guide to Stoke Poges Parish Church. Printed in Great Britain by MP\&D Ltd., n.d.

Harris, Reverend C. E. Thomas Gray, Poet, 1716-1771. A Guide to his Life and Works. Publisher unknown, n.d.

Howard, Anne (?). 'From The Good Shepherd's Sorrow for the Death of His Beloved Son' (1631). In: Alastair Fowler (ed.), The New Oxford Book of Seventeenth-Century Verse. Oxford: Oxford University Press, 2008, 10-11.

Macfarlane, Robert. The Old Ways: A Journey on Foot. London: Hamish Hamilton, 2012.

Macfarlane, Robert. Landmarks. London: Hamish Hamilton, 2015.

Montgomery, Robert. The Poetical Works. London: Chapman and Hall, 1854.

Seaton, Tony. 'Encountering Engineered and Orchestrated Remembrance: A Situational Model of Dark Tourism and its History.' In: Philip R. Stone, Rudi Hartmann, Tony Seaton, Richard Sharpley, and Leanne White (eds.), The Palgrave Handbook of Dark Tourism Studies. Basingstoke: Macmillan Publishers Ltd., 2018, 9-33.

Stowe, Harriet Beecher. Sunny Memories of Foreign Lands (1854). In two volumes. Boston: Phillips, Sampson, and Company, 1856.

Watson, Nicola J. The Literary Tourist. Basingstoke: Palgrave Macmillan, 2008.

\section{ABOUT THE AUTHOR}

James Metcalf is a visiting research fellow at the Centre for Life-Writing Research at King's College London. He recently completed his doctoral thesis entitled 'The Contemplators: Poetry and the Churchyard in the Long Eighteenth Century', which reappraises the conventional category of 'graveyard poetry' by focusing on the eighteenth-century occupation of the churchyard as the specific locus of a death-centred poetics of contemplation. Reconsidering the work of Thomas Parnell, Robert Blair, Edward Young, and Thomas Gray, James' thesis also reveals a continuity of poetic preoccupation with the churchyard by including traditionally 'Romantic' writers, such as Charlotte Smith and William Wordsworth, as they adopt and revise its history, culture and poetics. His current research interests concern literary responses to the revelations of earth science in the long eighteenth century. E-mail: james.metcalf@kcl.ac.uk. 


\section{NOTES}

1 The churchyard has always been a site of pilgrimage. Originally a plot of land enclosing the sacred relics of the martyrs, it preceded the associated church in ancient sites in Africa, Spain and Rome as the principal venerated space. Buildings were eventually constructed as martyria, memoriae, or chapels around saint's tombs, and only later supplemented with or replaced by a basilica to 'accommodate the large crowds of pilgrims attracted by the celebrity of the saint'. See Ariès, Philippe. The Hour of Our Death. Trans. Helen Weaver. Oxford: Oxford University Press, 1991 (34).

2 Howard, Anne (?). 'From The Good Shepherd's Sorrow for the Death of His Beloved Son' (1631). In: Alastair Fowler (ed.), The New Oxford Book of Seventeenth-Century Verse. Oxford: Oxford University Press, 2008 (11. 1-10).

3 On this theme I have been inspired by the work of Robert Macfarlane-see in particular The Old Ways: A Journey on Foot. London: Hamish Hamilton, 2012, and Landmarks. London: Hamish Hamilton, 2015. For a recent volume on this topic see also Dee, Tim (ed.). Ground Work: Writings on Places and People. London: Vintage, 2018.

4 Buczacki, Stefan. Earth to Earth: A Natural History of Churchyards. London: Unicorn Publishing Groups, 2018.

5 Deering, Bel. 'From Anti-Social Behaviour to X-Rated: Exploring Social Diversity and Conflict in the Cemetery.' In: Avril Maddrell and James D. Sidaway (eds.), Deathscapes: Spaces for Death, Dying, Mourning and Remembrance. Farnham: Ashgate Publishing Ltd., 2010 (79-80, 76).

6 Harris, Reverend C. E. A Guide to Stoke Poges Parish Church. Printed in Great Britain by MP\&D Ltd., n.d.

7 Harris, Reverend C. E. Thomas Gray, Poet, 1716-1771. A Guide to his Life and Works. Publisher unknown, n.d. (10-11).

8 Watson, Nicola J. The Literary Tourist. Basingstoke: Palgrave Macmillan, 2008 (41, 1). Thanatourism (also known as dark- or necro-tourism) is defined by visits that are organised around sites associated with death and destruction-ranging from churchyards, cemeteries, and ruins, to battlefields and locations of natural disasters and terrorist atrocities. Tony Seaton describes a much older chronology to this pull of the memorial-place, however, beginning with Christian pilgrimage and continuing through activities and spaces associated with antiquarianism and Romanticism. Each phase, though differently motivated, is arranged around journeys of remembrance to the places of the deadholy relics and shrines, ancestral tombs and memorials, and Gothic sites associated with 'Beautiful Death'. See Seaton, Tony. 'Encountering Engineered and Orchestrated Remembrance: A Situational Model of Dark Tourism and its History.' In: Philip R. Stone, Rudi Hartmann, Tony Seaton, Richard Sharpley, and Leanne White (eds.), The Palgrave Handbook of Dark Tourism Studies. Basingstoke: Macmillan Publishers Ltd., 2018 (21-22).

9 Gray, Thomas. 'Elegy Written in a Country Churchyard.' In: Roger Lonsdale (ed.), The Poems of Thomas Gray, William Collins, Oliver Goldsmith. London: Longmans, 1969 (1. 96).

10 Stowe, Harriet Beecher. Sunny Memories of Foreign Lands. Boston: Phillips, Sampson, and Company, 1856 (vol. II, 49-50); as quoted in Foster, Shirley. 'Americans and Anti-Tourism.' In: Nicola J. Watson (ed.), Literary Tourism and Nineteenth-Century Culture. Basingstoke: Palgrave Macmillan, 2009 (180).

11 Montgomery, Robert. 'The Tomb of Gray.' In: The Poetical Works. London: Chapman and Hall, 1854 (11. 40-42).

12 Hall, S. C. Pilgrimages to English Shrines. London: Arthur Hall, Virtue, \& Co., 1850 (104). 